\title{
The role of African buffalos (syncerus caffer) in the maintenance of foot-and-mouth disease in Uganda
}

\author{
Chrisostom Ayebazibwe ${ }^{1}$, Frank N Mwiine ${ }^{1,5}$, Kirsten Tjørnehøj ${ }^{3^{*}}$, Sheila N Balinda ${ }^{2}$, Vincent B Muwanika ${ }^{2}$, \\ Anna R Ademun Okurut ${ }^{1}$, Graham J Belsham ${ }^{3}$, Preben Normann ${ }^{3}$, Hans R Siegismund ${ }^{4}$, Soren Alexandersen ${ }^{3,6}$
}

\begin{abstract}
Background: To study the role of African buffalos (Syncerus caffer) in the maintenance of foot-and-mouth disease in Uganda, serum samples were collected from 207 African buffalos, 21 impalas (Aepyceros melampus), 1 giraffe (Giraffa camelopardalis), 1 common eland (Taurotragus oryx), 7 hartebeests (Alcelaphus buselaphus) and 5 waterbucks (Kobus ellipsiprymnus) from four major National Parks in Uganda between 2005 and 2008. Serum samples were screened to detect antibodies against foot-and-mouth disease virus (FMDV) non-structural proteins (NSP) using the Ceditest ${ }^{\oplus}$ FMDV NS ELISA. Solid Phase Blocking ELISAs (SPBE) were used to determine the serotypespecificity of antibodies against the seven serotypes of FMDV among the positive samples. Virus isolation and sequencing were undertaken to identify circulating viruses and determine relatedness between them.

Results: Among the buffalo samples tested, $85 \%(95 \% \mathrm{Cl}=80-90 \%)$ were positive for antibodies against FMDV non-structural proteins while one hartebeest sample out of seven $(14.3 \%$; $95 \% \mathrm{Cl}=-11.6-40.2 \%)$ was the only positive from 35 other wildlife samples from a variety of different species. In the buffalo, high serotype-specific antibody titres ( $\geq 80$ ) were found against serotypes O (7/27 samples), SAT 1 (23/29 samples), SAT 2 (18/32 samples) and SAT 3 (16/30 samples). Among the samples titrated for antibodies against the four serotypes O, SAT 1, SAT 2 and SAT 3, 17/22 (77\%; Cl = 59.4-94.6\%) had high titres against at least two serotypes.

FMDV isolates of serotypes SAT 1 (1 sample) and SAT 2 (2 samples) were obtained from buffalo probang samples collected in Queen Elizabeth National Park (QENP) in 2007. Sequence analysis and comparison of VP1 coding sequences showed that the SAT 1 isolate belonged to topotype IV while the SAT 2 isolates belonged to different lineages within the East African topotype $X$.

Conclusions: Consistent detection of high antibody titres in buffalos supports the view that African buffalos play an important role in the maintenance of FMDV infection within National Parks in Uganda. Both SAT 1 and SAT 2 viruses were isolated, and serological data indicate that it is also likely that FMDV serotypes O and SAT 3 may be present in the buffalo population. Detailed studies should be undertaken to define further the role of wildlife in the epidemiology of FMDV in East Africa.
\end{abstract}

\section{Background}

Foot-and-mouth disease (FMD) is a highly contagious viral disease that affects all cloven-hoofed wild and domestic animals [1] and has serious socio-economic consequences [2]. The epidemiology of FMD in Africa is unique, complex and poorly understood. Seven FMDV

\footnotetext{
*Correspondence: kitj@vet.dtu.dk

${ }^{3}$ National Veterinary Institute, Technical University of Denmark, Lindholm, DK-4771, Kalvehave, Denmark

Full list of author information is available at the end of the article
}

serotypes have been defined: O, A, C, Asia 1, and the Southern African Territories (SAT) 1, SAT 2 and SAT 3, of which all but Asia 1 have occurred in most East African countries including Uganda [3]. Wildlife hosts, especially African buffalos (Syncerus caffer), are believed to play an important role as reservoirs for the SAT serotypes of FMDV [4] and the disease is sometimes transmitted between and within different livestock and wildlife species [5-9].

\section{(Ciomed Central}


In Africa, the epidemiology of FMD is complicated by the widespread movement of animals, the wide host range of the virus involving wild and domestic animal reservoirs and the presence of multiple strains and substrains. Moreover, the spread of the disease is facilitated by the ability of the virus to survive for relatively long periods in raw meat, raw milk or outside the host $[1,10,11]$. Infection of cloven-hoofed animals can result in development of a carrier state in which case FMDV may be found in such animals for more than 28 days after infection [12-14], and thus may influence the epidemiology of the disease and interfere with its diagnosis and control. The duration of the carrier state can be prolonged after recovery from acute disease; in the case of cattle for up to 3.5 years [14]. The epidemiology of FMD in wildlife populations has not been fully documented but it has been established that African buffalo herds can harbour the infection for up to 24 years [15]. They act as long term maintenance hosts for the SAT serotypes (SAT 1, SAT 2 and SAT 3) of FMDV with no obvious clinical disease $[4,16]$. Other cloven-hoofed wildlife species may develop antibodies against FMD infections; however, their roles in excretion, transmission and persistence of FMDV either have not been conclusively studied or have been shown to be less important than the role of the buffalos $[7,17,18]$. In South Africa, the impala (Aepyceros melampus) has been shown to play a potentially significant role in the propagation of FMD outbreaks between livestock and wildlife [19].

FMD outbreaks are often encountered in cattle in Uganda but the roles of different wild and domestic hosts in the maintenance and spread of FMDV have not been exhaustively studied. Available data on seventy-three Ugandan FMD outbreaks, mainly in cattle, and a few isolates from apparently healthy buffalos, indicate that between the years 1958 and 2000, approximately $31 \%$ were attributed to serotype O, $26 \%$ to A, $25 \%$ to SAT $2,14 \%$ to SAT $1,3 \%$ to C and $1 \%$ to SAT 3 [3]. FMDV serotypes SAT 1, SAT 2 and SAT 3 have been found in many other sub-Saharan African countries, however, the viruses found in East Africa seem to belong to distinct lineages [20-22]. The possible role played by the African buffalos in the epidemiology of FMDV serotypes other than SATs has not been established, since only one single study in Queen Elizabeth National Park has reported antibodies against serotypes $O$ and $A$ [23], thus further research is required in this field.

This study was undertaken to evaluate the role of African buffalos and other wildlife species in the maintenance of different FMDV serotypes under natural conditions in selected National Parks in Uganda.

\section{Results}

Antibodies elicited against FMDV NSP

Between 2005 and 2008, 207 samples were collected from African buffalos and 35 samples were collected from other wildlife species (21 impala (Aepyceros melampus), 1 giraffe (Giraffa camelopardalis), 1 common eland (Taurotragus oryx), 7 hartebeest (Alcelaphus buselaphus) and 5 waterbuck, (Kobus ellipsiprymnus)) in Queen Elizabeth National Park (QENP), Lake Mburo National Park (LMNP), Kidepo Valley National Park (KVNP) and Murchison Falls National Park (MFNP). One hundred and seventy-six out of 207 buffalo samples (85\%; 95\% CI $=80-90 \%)$ tested positive for antibodies against FMDV NSP (Table 1), while only one of seven hartebeest samples $(14.3 \%$; 95\% CI $=-11.6-40.2 \%)$ from among those of other wildlife species tested positive in the NSP ELISA.

\section{Screening for serotype-specific antibodies using the Solid} Phase Blocking ELISA (SPBE)

Ninety-six percent $(131 / 137)$ of the buffalo samples tested were apparently positive for antibodies against more than one serotype in the screening dilution 1:5 in $\mathrm{SPBE}$. The proportion of positive samples was higher for serotypes SAT 1, SAT 2, SAT 3 and to a lesser extent serotype $\mathrm{O}$, than for serotypes $\mathrm{A}, \mathrm{C}$ and Asia 1 . One hartebeest tested positive for SAT 1, SAT 2, and SAT 3 (data not shown). Cross reactivity between the different serotypes is known to occur in such assays [17].

Table 1 Screening of serum samples from wildlife collected in four Ugandan National Parks during 20052008 for antibodies against the non-structural proteins of foot-and-mouth disease virus

\begin{tabular}{lllll}
\hline $\begin{array}{l}\text { National } \\
\text { Park }\end{array}$ & Species & $\begin{array}{l}\text { Total } \\
\text { samples } \\
\text { collected }\end{array}$ & $\begin{array}{l}\text { Number of } \\
\text { samples } \\
\text { tested }\end{array}$ & $\begin{array}{l}\text { Number of } \\
\text { positive } \\
\text { samples }\end{array}$ \\
\hline MFNP & Buffalo & 53 & 53 & $\mathbf{5 1}(\mathbf{9 6 \% )})$ \\
& Waterbuck & 5 & 5 & $\mathbf{0}(\mathbf{0} \%)$ \\
& Hartebeest & 7 & 7 & $\mathbf{1}(\mathbf{1 4 \% )}$ \\
LMNP & Giraffe & 1 & 1 & $\mathbf{0}(\mathbf{0} \%)$ \\
& Buffalo & 25 & 19 & $\mathbf{1 8}(\mathbf{9 5} \%)$ \\
& Impala & 21 & 21 & $\mathbf{0}(\mathbf{0} \%)$ \\
KVNP & Eland & 1 & 1 & $\mathbf{0}(\mathbf{0} \%)$ \\
QENP & Buffalo & 42 & 42 & $\mathbf{2 6}(\mathbf{6 2 \% )}$ \\
\hline & Buffalo & 94 & 93 & $\mathbf{8 1}(\mathbf{8 7 \% )}$ \\
\hline & Total & 214 & 207 & $\mathbf{1 7 6}(\mathbf{8 5} \%)$ \\
& buffalo & & & $\mathbf{1}(\mathbf{3} \%)$ \\
& Total & 35 & 35 & \\
\hline Total & Other & & & $\mathbf{1 7 7}$
\end{tabular}

(MFNP-Murchison Falls National Park, LMNP-Lake Mburo National Park, KVNPKidepo Valley National Park, QENP-Queen Elizabeth National Park). 
Titration of selected samples in relevant serotype-specific SPBEs

Samples from QENP, MFNP and LMNP were selected for titration on the basis of positive screening results and sufficient volumes with the objective of comparison of results across multiple years. A total of 37 buffalo samples were titrated in the relevant serotype-specific SPBEs as follows; O (27), SAT 1 (29), SAT 2 (32) and SAT 3 (30) as shown in Table 2. In this study, samples with titres of $\geq 80$ were considered positive based on the highest dilution at which non-specific reactions tended to disappear and the results of a previous study [24]. All the sera titrated for antibodies against serotypes A, C and Asia 1 had titres below 40 and were therefore considered negative (data not shown), while titres of 80 and above were found in the majority of sera titrated for antibodies against serotypes $\mathrm{O}(26 \% ; 95 \% \mathrm{CI}=9.5$ 42.6\%), SAT 1 (79\%; 95\% CI = 64.6-94.1\%), SAT 2 (56\%;

Table 2 Titres of serotype-specific antibodies against foot-and-mouth disease virus in serum samples from African buffalos collected in three National Parks in Uganda during 2005-2008

\begin{tabular}{|c|c|c|c|c|c|c|}
\hline National Park & Sample ID & Date & 0 & SAT 1 & SAT 2 & SAT 3 \\
\hline \multirow[t]{14}{*}{ LMNP } & BUF 3 & JAN.06 & - & - & 20 & - \\
\hline & BUF 2 & JAN.06 & 10 & 20 & 80 & - \\
\hline & BUF 7 & JAN.06 & - & - & 640 & 10 \\
\hline & BUF 1 & JAN.07 & 20 & 320 & 20 & - \\
\hline & BUF 6 & JAN.07 & 20 & 40 & 20 & 5 \\
\hline & BUF 10 & APR.07 & 160 & 640 & 80 & 640 \\
\hline & BUF 9 & APR.07 & 40 & 80 & 80 & 40 \\
\hline & BUF 11 & APR.07 & 10 & 20 & 40 & 40 \\
\hline & BUF 12 & APR.07 & - & 160 & - & 5 \\
\hline & BUF 6 & APR.07 & - & - & 40 & - \\
\hline & BUF 1 & ОСТ.08 & - & 640 & - & 80 \\
\hline & BUF 4 & OCT.08 & - & 80 & 40 & 20 \\
\hline & BUF 5 & Ост.08 & - & 80 & - & - \\
\hline & BUF 6 & ОСТ.08 & - & 80 & 20 & 20 \\
\hline \multirow[t]{10}{*}{ MFNP } & BUF 2 & OCT.05 & 160 & 320 & 80 & 160 \\
\hline & BUF 7 & OCT.05 & 5 & 320 & 160 & 320 \\
\hline & BUF 15 & OCT.05 & 320 & 640 & 160 & 160 \\
\hline & BUF 2 & NOV.06 & 5 & 10 & 320 & 20 \\
\hline & BUF 3 & NOV.06 & 20 & 80 & 40 & 80 \\
\hline & BUF 7 & NOV.06 & 40 & 80 & 10 & 80 \\
\hline & BUF 12 & OCT.07 & 40 & 80 & 160 & 160 \\
\hline & BUF 5 & ОСТ.07 & 20 & 20 & 20 & 160 \\
\hline & BUF 20 & Ост.07 & 40 & 640 & 40 & 320 \\
\hline & BUF 18 & ОСТ.07 & 640 & 640 & 320 & 320 \\
\hline \multirow[t]{13}{*}{ QENP } & BUF 17 & JAN.07 & 5 & 160 & 80 & 20 \\
\hline & BUF 37 & APR.07 & 5 & 20 & 40 & 20 \\
\hline & BUF 35 & APR.07 & - & - & 320 & 40 \\
\hline & BUF 8 & JUL.07 & 80 & 320 & 160 & 40 \\
\hline & BUF 9 & AUG.07 & 20 & 320 & 320 & 160 \\
\hline & BUF 3 & AUG.07 & 160 & 640 & 80 & 320 \\
\hline & BUF 13 & AUG.07 & 80 & 640 & 80 & 160 \\
\hline & BUF 1 & ОСТ.08 & 5 & - & 40 & 160 \\
\hline & BUF 2 & Ост.08 & 40 & 640 & 40 & 80 \\
\hline & BUF 3 & ОСТ.08 & 10 & 80 & 320 & 20 \\
\hline & BUF 5 & Ост.08 & - & - & 80 & 40 \\
\hline & BUF 6 & ОСТ.08 & 10 & - & - & - \\
\hline & BUF 9 & ОСТ.08 & 40 & - & - & - \\
\hline Total & & & $7 / 27$ (26\%) & $23 / 29(79 \%)$ & $18 / 32$ (56\%) & $16 / 30(53 \%)$ \\
\hline
\end{tabular}

Minus signs (-): results of samples with titres $<5$ in the screening test and thus not titrated.

Bold figures: results of samples tested positive (ODP $\geq 80$ ) 
95\% CI $=39.1-73.4 \%)$ and SAT 3 (53\%; 95\% CI = 35.45$71.2 \%)$. The samples positive for antibodies against FMDV serotype $\mathrm{O}$ were also positive for at least two of the SAT serotypes. Six of 22 (27\%; 95\% CI = 8.7-45.9\%) samples titrated for antibodies against all three SAT serotypes as well as against serotype $\mathrm{O}$ were positive for all four serotypes, while 17 (77\%; 95\% CI = 59.5-94.6\%) were positive for at least two serotypes. Nine of the 24 samples titrated for antibodies against all three SAT serotypes were positive for antibodies against all 3 serotypes, including at least one buffalo in each of QENP, LMNP and MFNP.

\section{Isolation and identification of FMDV}

Three FMDV isolates were obtained in primary bovine thyroid cells from among nine buffalo probang samples collected on the same day in January 2007 in QENP, and were identified by antigen ELISA as SAT 1 (1 sample from BUF 17) and SAT 2 (from BUF 6 and BUF 10). BUF 17 had a higher titre of antibodies against SAT 1 (160) compared to those against SAT 2 (80) and SAT 3 (20) (Table 2), while the sera of BUF 6 and BUF 10 were not titrated in the SPBE. Following RT-PCR, the near complete genome sequences were obtained and blasted in the GenBank data base. The sequencing data was entirely consistent with the antigen ELISA results in terms of serotype identification. Due to the limited number of full length SAT serotype sequences that are available, comparative analysis of the virus sequences was restricted to the VP1 coding region. These sequences were compared to reference strains for the defined topotypes [25] to assess the phylogenetic relationships (Figure 1 and 2). The SAT 1 isolate (SAT 1/ UGA/1/07, [GenBank HM067706]) was most closely related (pair wise identity of $83 \%$ ) to a previous isolate obtained from a buffalo in Uganda in 1970 (SAT 1/ UGA BUFF/21/70, Knowles et al., unpublished) belonging to the East African topotype IV (Figure 1). The two SAT 2 isolates were closely related to each other (pair wise identity of 90.4\%) and grouped with representatives of the topotype $\mathrm{X}$ viruses (Figure 2). One of the isolates, SAT 2/UGA/1/07 [GenBank HM067705], was also related to an isolate from cattle in the neighbouring country of Democratic Republic of Congo (pair wise

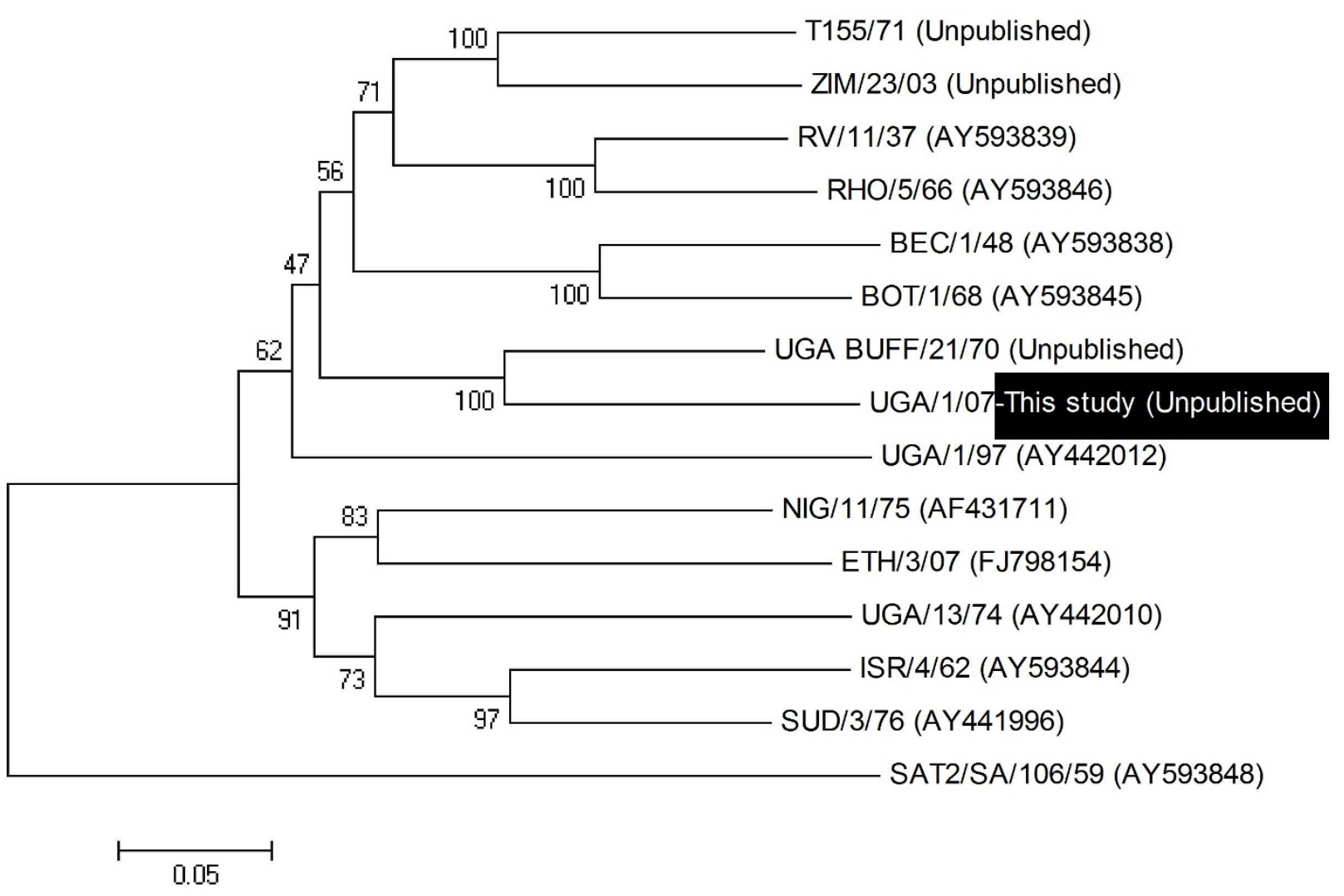

Figure 1 Neighbour-joining tree depicting VP1 coding sequence relationships of the recent Ugandan SAT 1 isolate (SAT 1/UGA/07) with other SAT 1 reference prototypes from WRLFMD, Pirbright. Bootstrap values $\geq 50$, based on 1,000 replicates are indicated next to the relevant node. 


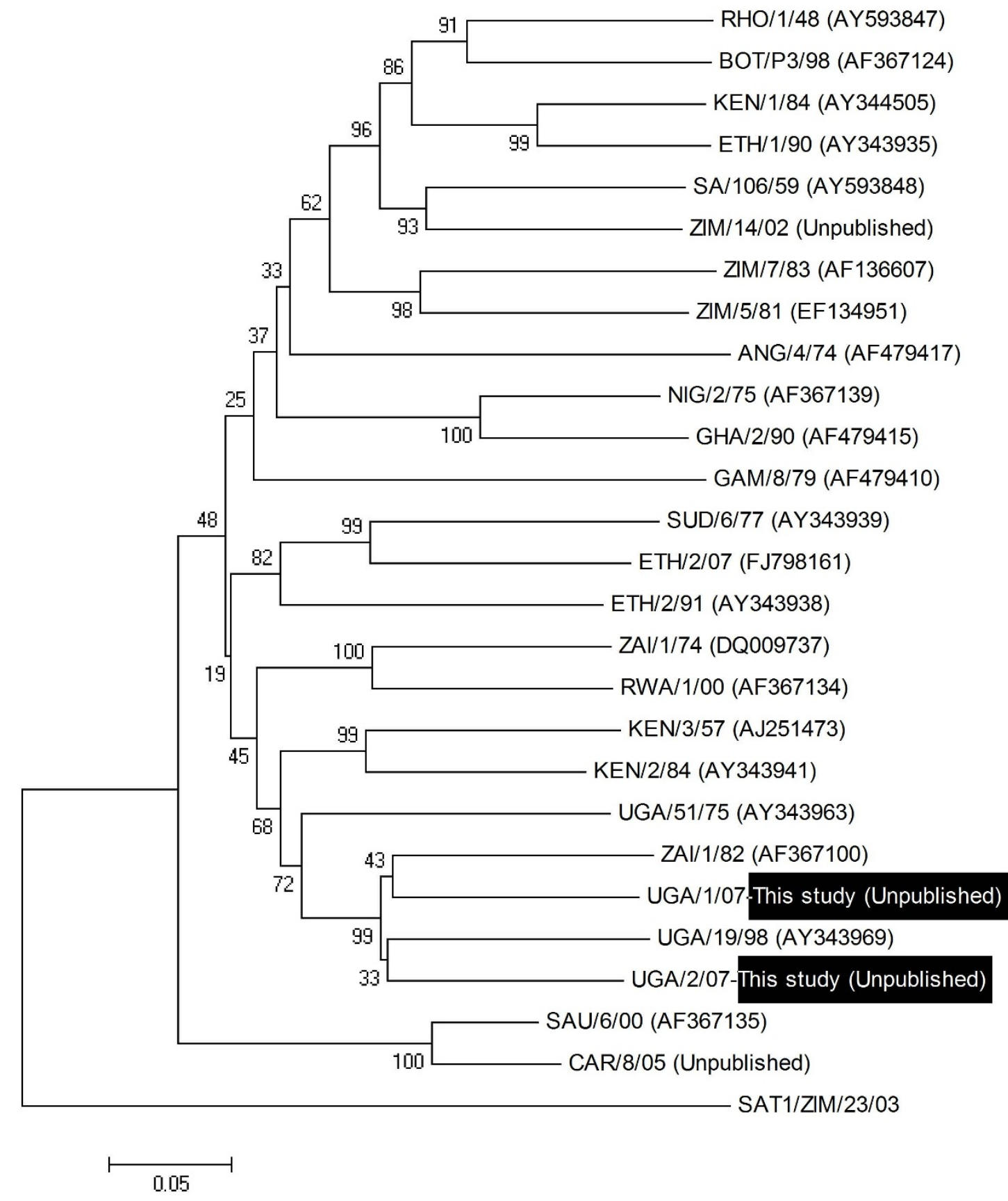

Figure 2 Neighbour-joining tree depicting VP1 coding sequence relationships of the recent Ugandan SAT 2 isolates (SAT 2/UGA/1/07 and SAT 2/UGA/2/07) with other SAT 2 reference prototypes from WRLFMD, Pirbright. Bootstrap values $\geq 50$, based on 1,000 replicates are indicated next to the relevant node.

identity 89.5\%), while the other, SAT 2/UGA/2/07 [GenBank HM067704], was related to a previous isolate from a buffalo in Uganda (SAT 2/UGA/1998, accession number AY343969) with pair wise identity of $89.6 \%$. There were multiple amino acid differences between the SAT 2 viruses within the G-H loop (residues 140-160) and the C- terminal region of VP1 which correspond to known antigenic sites (Figure 3). The recent SAT 2 buffalo isolates had some amino acid differences, within the hyper-variable regions surrounding the conserved RGD cell attachment motifs, compared to those obtained from postoutbreak slaughtered cattle in Uganda in 2004 [26]. 


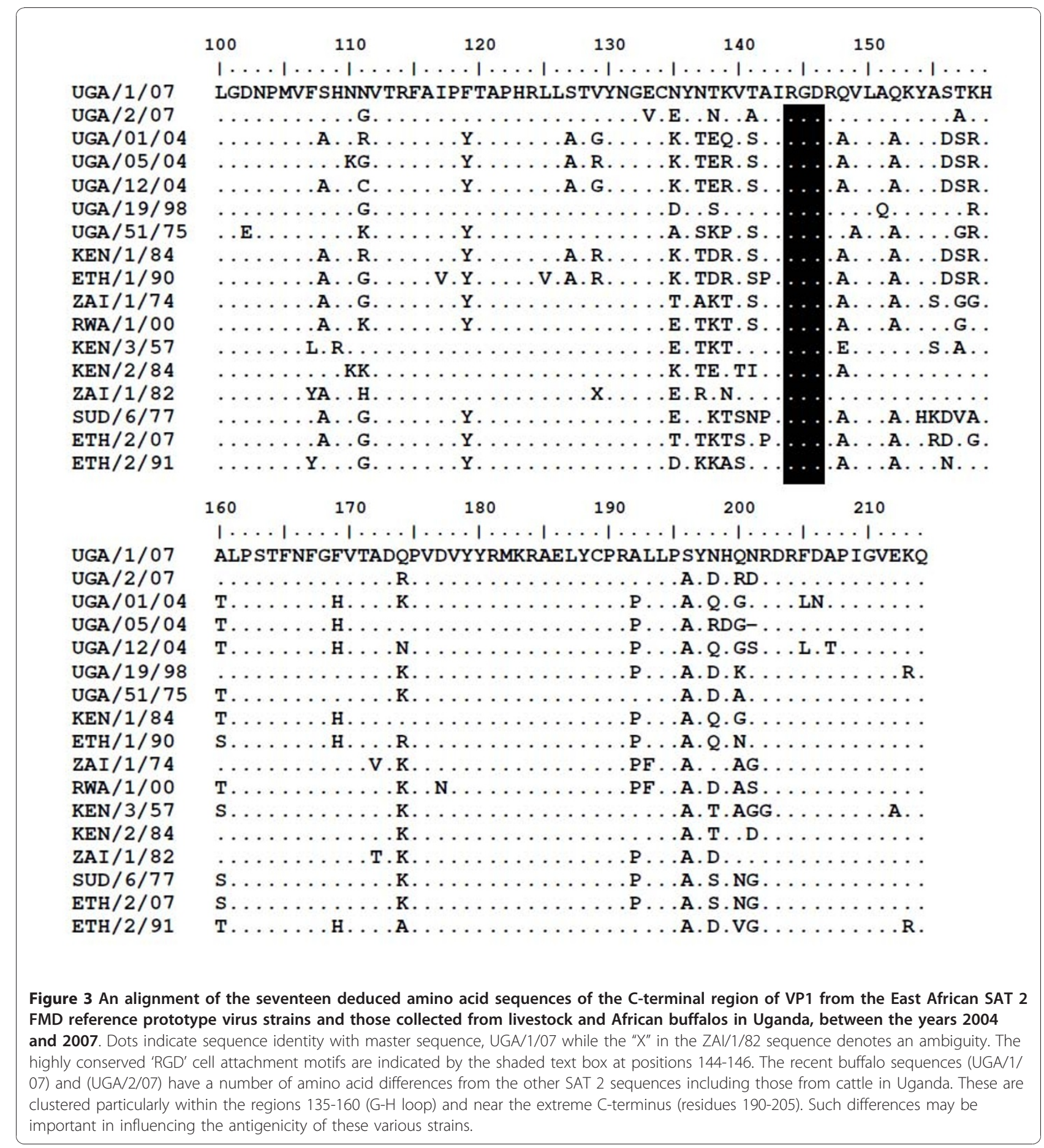

\section{Discussion}

Antibodies against FMDV were detected by both the Ceditest $^{\oplus}$ FMDV NS kit and the SPBE in over $80 \%$ of screened buffalo samples. Among the samples of wildlife species other than the buffalos, it was only one from a hartebeest that had detectable antibodies against FMDV. Due to small sample sizes in other tested wildlife species, it is, at this stage, not possible to explain or conclude anything about the importance of these other species relative to buffalos. However, the findings of this study do relate to those of other studies done elsewhere. It has been indicated that a number of wild ruminants become persistently infected with FMDV but it is only the African buffalos that have been shown to spread the 
infection during the carrier state [16,27]. The situation seems to be different within the impala population in the Kruger National Park in South Africa, where clinical FMD has been reported, and subclinical infections have been shown to occur much more regularly than previously suspected [19]. It is hypothesized that during the acute state of the disease some species may act as intermediaries in the transmission of FMD, mainly between buffalos and cattle $[6,18,19]$. The current findings concur with reports of very low seroprevalence of antibodies against FMDV in non-buffalo wildlife species $(4.4 \%)$ compared to buffalos (67.7\%) in Eastern Africa [17]. The Ceditest $^{\oplus}$ NSP ELISA seemed to work well in detecting antibodies against FMDV in buffalo samples, with estimates of sensitivity and specificity at $87.7 \%$ and $87.3 \%$, respectively [17].

In this study, the majority of the buffalos were positive for antibodies against FMDV NSP during each of the sampling trips between the years 2005 and 2008. This indicates that infection is almost always present in the sampled National Parks. Persistent infections within buffalo herds have been reported to occur in Southern Africa due to most calves becoming infected with the three SAT serotypes, when maternal antibodies wane at 2-6 months of age, thereby creating an opportunity for transmitting the infection to other susceptible species [28-30]. The current findings justify the need to conduct much more in-depth age-stratified longitudinal studies to confirm the serotypes and patterns of FMD in different localities in Uganda.

SPBE screening results (dilution 1:5) were difficult to interpret due to the large percentage (96\%) of animals apparently testing positive for antibodies against more than one serotype. However, titrations showed that reactions in the serotype $A, C$ and Asia 1 antibody ELISAs were most likely cross-reactions. This fits well with the lack of any reports of such serotypes in wildlife in Uganda, the almost complete disappearance of serotype $C$ from the world and the fact that serotype Asia 1 has never been reported anywhere on the African continent [3].

This is the first time the SPBEs have been used in an unvaccinated animal population like the buffalos, which probably harbour persistent infections with multiple serotypes. For future studies in endemic conditions, sera should be screened in dilution 1:10, and the SPBE ELISAs should be improved by using more purified antigens and more recent FMDV strains representing the FMDV topotypes currently circulating in Uganda for the production of reagents and positive sera, thereby possibly enhancing the specificity.

Screening of samples by serotype-specific SPBE worked well for selection for further titration, thereby significantly reducing the associated working time and expense. Titrations demonstrated the highest antibody titres against serotypes SAT 1, SAT 2 and SAT 3 with the exception of one out of four buffalos sampled in MFNP in 2007 that had equally high titres against serotypes $\mathrm{O}$ and SAT 1.

It is thus evident from the present study, that buffalos were exposed to the FMDV SAT serotypes, and in MFNP probably also to serotype $O$. These findings suggest that African buffalos may play an important role as natural reservoirs of the SAT serotypes of FMDV in East Africa and are consistent with what has been established in Southern Africa [31-33]. Detection of antibodies against serotype $\mathrm{O}$ in this study confirms previous reports of antibodies against other FMDV serotypes than the SATs in buffalos in QENP [23].

The distribution of serotypes varied between the National Parks and between sampling trips. In this study, a large proportion of the buffalo samples had high antibody titres against more than one serotype of FMDV (77\%), and this is consistent with previous research findings $[17,23,24]$. The relative antibody prevalences found in this study $($ SAT $1>$ SAT $2>$ SAT $3>$ O) differ from those of Bronsvoort et al. [17], who found that antibodies against SAT 2 were the most prevalent, followed by SAT 1 and finally SAT 3, in African buffalos in Eastern Africa. This is likely due to spatial and temporal differences in the distribution of the infection.

Three FMDV isolates consisting of one SAT 1 from a buffalo in one herd and two SAT 2 from buffalos in another herd were obtained from three out of nine African buffalo probang samples collected on the same day in 2007 in QENP indicating the presence of either current or persistent infection. The three isolates were characterised using antigen ELISA and by full-length sequencing. The VP1 coding regions of the two SAT 2 isolates showed that these viruses belonged to the same topotype (X) but different lineages, with $90.4 \%$ pair wise identity. One of the SAT 2 isolates (SAT 2/UGA/1/07) was most closely related with a previous isolate (SAT 2/ $\mathrm{ZAI} / 1 / 82$ [AF367100]) from cattle in the neighbouring country of Democratic Republic of Congo (89.5\% pair wise identity) indicating a possibility of cross-border and wildlife-livestock transmission. The SAT 1 sequence was closest to a representative of the topotype IV isolate obtained in 1970 from a buffalo in Uganda (SAT 1/ UGA BUFF/21/70, N. Knowles, unpublished) with a pair wise identity of $83 \%$. It is clear from this study that the viruses obtained are different from each other. These differences may be of particular significance during selection of strains that may be considered for vaccine manufacture and effective control of foot-and-mouth disease due to a range of viruses that may be shared between wildlife and livestock. The isolation and 
characterization of these viruses from buffalo confirms the presence of SAT 1 and SAT 2 types of FMDV as demonstrated serologically by SPBEs. More molecular epidemiological studies are necessary for precise elucidation of the diversity of FMDV genotypes and the possible challenges involved in matching such strains with those included in vaccines produced for use in Uganda. Molecular studies including the current SAT 1 virus in this study suggest that a unique group of SAT 1 viruses exist in Uganda and, may necessitate a regional approach for effective control [34].

Consistent evidence of antibodies against multiple serotypes of FMDV in several Ugandan National Parks and the isolation of SAT 1 and SAT 2 in QENP in 30\% of nine apparently healthy buffalos indicates that wildlife maintains FMDV infections, and thus re-affirms recent findings in buffalo sera collected during 2001-2003 [34]. These findings combined with serological evidence of exposure of cattle grazing in QENP to the SAT serotypes [35] emphasizes the need to study FMDV isolates from these two populations to establish whether FMDV is transferred between them and at which rate.

FMDV serotype SAT 3 was isolated from a buffalo in QENP in 1970 [36] and this study indicates that this serotype may still be present. It is not clear why outbreaks caused by serotype SAT 3 have never been confirmed in cattle, while outbreaks of FMDV SAT 1 and SAT 2 are quite frequent in the region.

The findings of this study highlight the challenges involved in the diagnosis and control of FMD in endemic areas and emphasize the need for optimization of the methods used for serological diagnosis and for serotyping of FMDV outbreaks. There is need for more studies to investigate detailed epidemiology of FMD in wildlife in Uganda.

\section{Conclusions}

African buffalos are important for the maintenance of FMDV within National Parks of Uganda. They play an important epidemiological role in the circulation of FMDV serotypes SAT 1 and SAT 2, and may also harbour serotype SAT 3 and $\mathrm{O}$ infections.

\section{Methods}

\section{Study area}

The present study was kindly approved by Uganda Wildlife Authority (UWA/PMR/RES/50) and wildlife samples were collected from four major National Parks in Uganda, namely; QENP, LMNP, MFNP and KVNP (Figure 4). These National Parks were chosen on the basis of the high chance of livestock-wildlife interactions. Compared to other National Parks in Uganda, they are generally flat or gently sloping and not densely covered by vegetation thereby facilitating the exercise of darting and follow up of the sedated animals. Such National Parks are also home to sizeable buffalo populations with estimates of about 6,807 animals in QENP, 132 in LMNP, 8,200 in MFNP and 400 in KVNP [37]. All the national parks are unfenced and hence provide possibilities for livestock-wildlife interactions.

Due to the large buffalo population and the very high chances of livestock-wildlife interactions, more samples were collected in QENP than in the other parks.

\section{Sampling}

Apart from the impala, chemical capture was used for immobilization of animals of choice $[38,39]$. The original target of sampling at least $10 \%$ of each herd was not possible. Most buffalo herds would disperse and sometimes scatter to inaccessible areas upon darting one or a few of them. At times it would be impossible to locate herds in the National Parks. Animals were darted with a Dan-Inject dart gun. Two cars were used; one for the identifying and darting the animals and the other for tracking the herds, general field support and tracing the darted animal. Buffalo herds were located and animals moving at the edge of the group identified and darted. The anaesthetic combination was 8-10 mg Etorphine (Kyron, South Africa) and 70-90 mg Xylazine (Kyron, South Africa). The sedated animal would be cautiously located and approached, held by the horns and head, blindfolded and the mouth opened and the tongue pulled out for examination for lesions and ensuring continuous respiration before collection of serum and probang samples. After sampling, the sedative was reversed by use of a combination of 14-18 mg Diprenorphine and 60-70 mg Yohimbine (Kyron, South Africa) by intravenous infusion through the ear vein. The age of the buffalos was estimated from the teeth. All buffalos fell within the age group used for rinderpest serosurveillance (1.8-20 years). Non-buffalo species other than the impala were also darted following similar techniques as defined by Kock et al. [39]. Due to significant challenges of chemical capture, impala were instead physically restrained after dazzling them with strong light directed at the eyes at night time, during periods of little or no moonlight [40].

A total of 134 African buffalo samples and 21 impala samples were collected during 16 trips in the years 2007 and 2008 (Table 1). The samples from giraffe (1), hartebeest (7) and waterbuck (5), were jointly obtained through the on-going wildlife health research and monitoring programmes by Uganda Wildlife Authority in 2007. Eighty African buffalo samples and 1 Eland sample had been collected during the rinderpest serosurveillance exercise between the years 2005 and 2006 . Probang samples were preserved in $0.04 \mathrm{M}$ phosphate buffered saline (PBS), transported under liquid nitrogen 


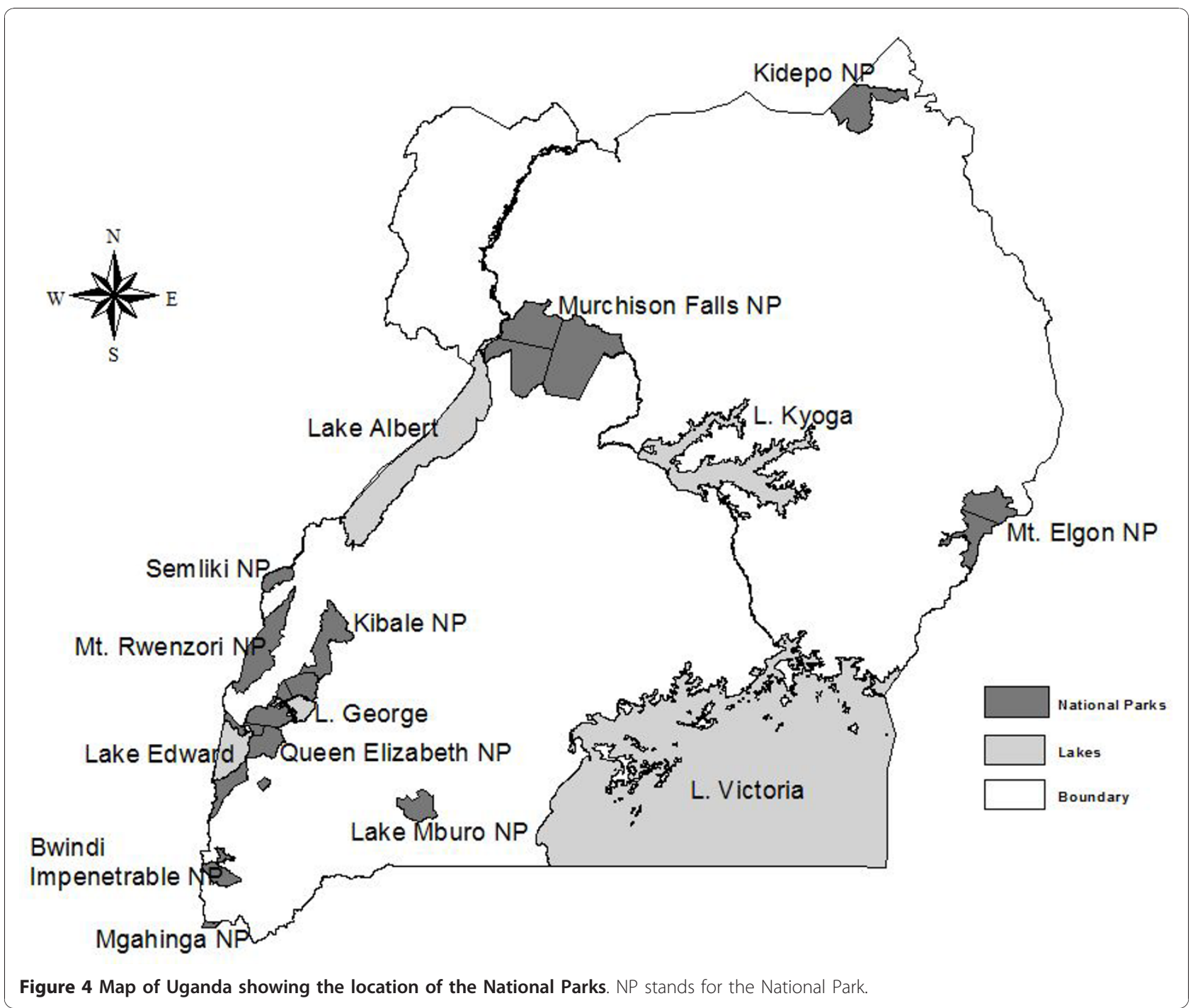

while in the field and stored at $-80^{\circ} \mathrm{C}$ at the laboratory. Serum was separated from blood and stored at $-20^{\circ} \mathrm{C}$ in the laboratory.

Screening for antibodies to FMDV non-structural proteins 207 buffalo samples were screened for antibodies against non-structural proteins (NSP) of FMDV using the commercial Ceditest FMDV NS ${ }^{\bullet}$ kit (Cedi diagnostics BV, Netherlands) [41]. This test is currently marketed as Priocheck ${ }^{\ominus}$ FMDV NS by Prionics ${ }^{\bullet}$ AG, Switzerland. In addition, samples from impala $(\mathrm{n}=21)$, hartebeest $(\mathrm{n}=$ $7)$, waterbuck $(n=5)$, eland $(n=1)$ and giraffe $(n=1)$ were tested in the same way.

Serotype-specific Solid Phase Blocking ELISA (SPBE)

137 African buffalo serum samples, of which seven were not tested for antibodies against NSP, were screened (dilution 1:5) for serotype-specific antibodies against FMDV using an in-house SPBE system modified from Have and Holm-Jensen [42] and described in detail by Balinda et al. [43]. The O, A, C and Asia 1 tests in this ELISA system have been used at the National Veterinary Institute, Danish Technical University (Lindholm), for many years; they have been validated for cattle and swine (ISO/IEC 17025) and used for many other ruminants and Camelidae with good results, and they appear to work well on all species (Alexandersen, unpublished results). The SPBE tests for antibodies against the SAT-serotypes were more recent and were still undergoing evaluation. Closely related ELISA tests for the SAT-serotypes have been set up and used under African conditions for detecting antibodies against multiple FMDV serotypes and shown to perform well $[43,44]$. 
For each well, optical density (OD) as a percentage of the mean $\mathrm{OD}$ of four wells with negative control sera (ODP) was calculated according to the formula: ODP = ((sample $\left.\mathrm{OD}_{450}-\mathrm{OD}_{620}\right) /($ mean of (negative control sera $\left.\left.\mathrm{OD}_{450}-\mathrm{OD}_{620}\right)\right) \times 100$. Samples were considered positive, if ODP was lower than $50 \%$ in the antibody tests for O, SAT 1, SAT 2 and SAT 3, 45\% for A and $35 \%$ for $C$ and Asia 1.

Based on the serological status and availability of sufficient amounts, 37 positive samples were selected and titrated (up to dilution 1:640) in the relevant serotype specific SPBEs. Titres were expressed as the reciprocal of the highest positive dilution.

Due to limited sample volumes and the smaller number of trips made, serotype specific SPBE studies did not include KVNP.

\section{FMD Virus isolation and antigen ELISA}

The methodology of virus isolation from the OP samples was adopted from the standard procedure described by the World Organisation for Animal Health [45]. Briefly, $50 \mu \mathrm{l}$ of undiluted sample and a 1:10 dilution of the sample were each inoculated into 5 wells of a 96well microtitre plate with monolayers of primary bovine thyroid (BTY) cells and $100 \mu$ l of Eagles media with $2 \%$ fetal calf serum. A row of wells with negative control sera including buffer was inserted between each sample. The cell cultures were incubated at $37^{\circ} \mathrm{C}$ and examined for cytopathic effect (CPE) for 2-4 days. Negative cultures were passaged onto new bovine thyroid (BTY) monolayers once. First and second passage cultures with CPE were harvested and serotyped using an in-house antigen ELISA set up at the National Veterinary Institute, Lindholm, Denmark, based on the description by OIE [45]. Briefly, the rabbit and guinea pig hyperimmune sera were the same as used in the in-house SPBE for serotype-specific antibodies against FMDV described above. The samples were tested in duplicate, and for each serotype each plate included two wells with strong positive control sera, two wells with weak positive control sera and two wells with negative control sera, all consisting of cell-culture materials. The tests for serotypes $\mathrm{O}, \mathrm{A}, \mathrm{C}$ and Asia 1 were quality assured (ISO/IEC 17025), while the tests for serotypes SAT 1, SAT 2 and SAT 3 were more recently set up and still undergoing evaluation.

\section{RNA extraction, RT-PCR and cycle sequencing}

Total RNA was extracted from CPE positive cell cultures using the RNeasy-Mini Kit ${ }^{\oplus}$ (Qiagen, Germany) according to the manufacturer's instructions. cDNA was synthesized from the template using Ready-To- $\mathrm{Go}^{\circ} \mathrm{You}$-Prime First-Strand Beads (GE Healthcare Life Sciences, UK) and a four-primer mix of $\mathrm{NVT}_{24}$, A PN 63 (5'-
AGACCTGGAAAGACCAGGC-3'), $\mathrm{G}_{15} \mathrm{H}$, and pdN6 (random hexamers). To generate 15 overlapping PCR fragments for near full length genome sequencing, 15 PCR-tubes were prepared containing: $33.1 \mu \mathrm{l}$ of water, $5.0 \mu \mathrm{l} 5 \times$ AmpliTaq Gold buffer, $4.0 \mu \mathrm{MgCl}_{2}(25 \mathrm{mM})$, $0.4 \mu \mathrm{ldNTPs}$ (2.5 mM each), 2.5 Units of Amplitaq Gold $^{\oplus}$ (Applied Biosystems, UK) and $5.0 \mu \mathrm{l}$ of template cDNA. To each of these tubes, $1.0 \mu \mathrm{l}$ of respective fragment-specific forward and reverse primers, each at a concentration of $25 \mathrm{pmol} / \mu \mathrm{l}$ was added to make a total volume of $50 \mu \mathrm{l}$.

The primers used for the VP1 coding region are shown in Table 3. The PCR (Perkin Elmer PE 9700) was set and ran at $95^{\circ} \mathrm{C}$ for 5 minutes to activate Amplitaq enzyme followed by five cycles $\left(95^{\circ} \mathrm{C}\right.$ for 15 seconds, $55^{\circ}$ $\mathrm{C}$ for 30 seconds with less by 1 second in each subsequent cycle and then $72^{\circ} \mathrm{C}$ for 1 minute and $20 \mathrm{sec}$ onds), 40 cycles $\left(95^{\circ} \mathrm{C}\right.$ for 15 seconds, $50^{\circ} \mathrm{C}$ for 30 seconds, and $72^{\circ} \mathrm{C}$ for 1 minute and 20 seconds-adding 1 second per cycle) and lastly at $72^{\circ} \mathrm{C}$ for 7 minutes and kept at $4^{\circ} \mathrm{C}$. To confirm the presence or absence of PCR products, gel electrophoresis was undertaken using $1.2 \%$ agarose containing $0.005 \%$ ethidium bromide. Amplicons were extracted from the gel using the Qiaquick ${ }^{\odot}$ (Qiagen, Germany) gel extraction kit and sent to AGOWA (Germany) for cycle sequencing.

\section{Sequence analysis}

A phylogenetic tree of the virus sequences was inferred using the Neighbor-Joining method [46]. The bootstrap consensus tree inferred from 1000 replicates is taken to represent the evolutionary history of the taxa analyzed [47]. The evolutionary distances were computed using the Kimura 2-parameter method [48] and are in the units of the number of base substitutions per site. The sequences studied were all from the VP1 coding region of the current FMDV isolates and the reference topotypes (Table 4). All positions containing gaps and missing data were eliminated from the dataset. There

Table 3 List of primers used for RT-PCR. For each fragment, forward and reverse primers were used

\begin{tabular}{lll}
\hline $\begin{array}{l}\text { Sample } \\
\text { ID }\end{array}$ & Forward Primers $\left(\mathbf{5}^{\prime}\right.$ to $\left.\mathbf{3}^{\prime}\right)$ & Reverse primers $\left(\mathbf{5}^{\prime}\right.$ to $\left.\mathbf{3}^{\prime}\right)$ \\
\hline BUF $\mathbf{1 0}$ & CAGTACTCCGGCAGCCTG & GGTGTTGTAATTGCACTCTCC \\
& CAGTGGTGTTCTCGCACAAC & GCCATDGGMGGGATGAACCC \\
BUF 6 & GACCGTATTCTCACCACGAG & AAGTTGGACCTGACGTCGG \\
BUF 17 & CAAAXAGGGATITXCCCGTXGC & GACGACXGGXTTGCGCC \\
& CTGGTXGGCGCAATCCTXCGT & CGGTTRAAGTCGGWCCGTG
\end{tabular}

The sequences obtained from samples BUF 10, BUF 6 and BUF 17 were subsequently named SAT 2/UGA/1/07, SAT 2/UGA/2/07 and SAT 1/UGA/1/07, respectively. These samples were all collected on the same day $(17 / 1 / 07)$ in Queen Elizabeth National Park, but BUF 17 was from a different herd. 
Table 4 Summary of the Viruses used in this study

\begin{tabular}{|c|c|c|c|c|}
\hline Serotype & Host Animal & Virus strain & GenBank accession no. & Country \\
\hline \multirow[t]{14}{*}{ SAT 1} & Buffalo & SAT1/UGA/1/07* & HM067706 & Uganda \\
\hline & - & SAT1/T155/71* & N/A & Tanzania \\
\hline & - & SAT1/ZIM/23/2003 & N/A & Zimbabwe \\
\hline & - & SAT1/RV/11/37 & AY593839 & Unknown \\
\hline & - & SAT1/RHO/5/66 & AY593846 & Rhodesia \\
\hline & - & SAT1/BEC/1/48 & AY593838 & Botswana \\
\hline & - & SAT1/BOT/1/68 & AY593845 & Botswana \\
\hline & Buffalo & SAT1/UGABUFF/21/70 & $\mathrm{N} / \mathrm{A}$ & Uganda \\
\hline & - & SAT1/NIG/11/75 & AF431711 & Nigeria \\
\hline & - & SAT1/ISR/4/62 & AY593844 & Israel \\
\hline & - & SAT1/SUD/3/76 & AY441996 & Sudan \\
\hline & - & SAT1/UGA/13/74 & AY442010 & Uganda \\
\hline & - & SAT1/UGA/1/97* & AY442012 & Uganda \\
\hline & Cattle & SAT1/ETH/3/2007 & FJ798154 & Ethiopia \\
\hline \multirow[t]{29}{*}{ SAT 2} & Cattle & SAT2/UGA/01/2004* & GU323171 & Uganda \\
\hline & Cattle & SAT2/UGA/05/2004* & GU323174 & Uganda \\
\hline & Cattle & SAT2/UGA/12/2004* & GU323179 & Uganda \\
\hline & Buffalo & SAT2/UGA/1/2007* & HM067705 & Uganda \\
\hline & Buffalo & SAT2/UGA/2/2007* & HM067704 & Uganda \\
\hline & - & SAT2/SA/106/59 & AY593848 & Unknown \\
\hline & - & SAT2/ZIM/14/2002 & $\mathrm{N} / \mathrm{A}$ & Zimbabwe \\
\hline & Cattle & SAT2/ZIM/7/83* & AF136607 & Zimbabwe \\
\hline & - & SAT2/ZIM/5/81 & EF134951 & Zimbabwe \\
\hline & - & SAT2/RHO/1/48 & AY593847 & Rhodesia \\
\hline & Buffalo & SAT2/BOT/P3/98 & AF367124 & Botswana \\
\hline & Cattle & SAT2/KEN/1/84 & AY344505 & Kenya \\
\hline & Cattle & SAT2/ETH/1/90 & AY343935 & Ethiopia \\
\hline & Cattle & SAT2/NIG/2/75 & AF367139 & Nigeria \\
\hline & Cattle & SAT2/GHA/2/90 & AF479415 & Ghana \\
\hline & Cattle & SAT2/GAM/8/79 & AF479410 & Gambia \\
\hline & Cattle & SAT2/SAU/6/2000 & AF367135 & Saudi Arabia \\
\hline & - & SAT2/CAR/8/2005 & $\mathrm{N} / \mathrm{A}$ & Cameroon \\
\hline & - & SAT2/ZAI/1/74 & DQ009737 & DRC \\
\hline & Cattle & SAT2/RWA/1/00* & AF367134 & Rwanda \\
\hline & Cattle & SAT2/KEN/3/57 & AJ251473 & Kenya \\
\hline & Cattle & SAT2/KEN/2/84 & AY343941 & Kenya \\
\hline & - & SAT2/ZAI/1/82 & AF367100 & Zaire \\
\hline & Cattle & SAT2/UGA/19/98 & AY343969 & Uganda \\
\hline & - & SAT2/ANG/4/74 & AF479417 & Angola \\
\hline & Cattle & SAT2/UGA/51/75 & AY343963 & Uganda \\
\hline & Cattle & SAT2/SUD/6/77 & AY343939 & Sudan \\
\hline & Cattle & SAT2/ETH/2/2007 & FJ798161 & Ethiopia \\
\hline & Cattle & SAT2/ETH/2/91 & AY343938 & Ethiopia \\
\hline
\end{tabular}

*: not WRLFMD reference numbers.

-: host animal not indicated.

NA: not applicable.

were a total of 660 nucleotides in the final dataset. Phylogenetic analyses were conducted in MEGA 4 $[49,50]$. In order to deduce the amino acid sequences, the East African SAT 2 prototype sequences together with the Ugandan buffalo sequences (this study) and those from cattle during 2004 [26] corresponding to the $\mathrm{C}$-terminal part of the VP1, were aligned and translated in MEGA 4 and exported to the Bioedit sequence alignment editor [51] to identify the positions of differences and similarities. 


\section{Acknowledgements}

We acknowledge the cooperation of Pan African Control of Epizootics (PACE) project, Uganda Wildlife Authority and the Ministry of Agriculture Animal Industry and Fisheries (MAAIF), Uganda for allowing us to analyze samples originally collected for rinderpest sero-surveillance. Dr. Charles Masembe was very useful in sample collection and general project work. Dr. Patrick Atimnedi was very instrumental in the darting of wild animals for collection of samples. Dr. Abraham Kiprotich Sangula participated in some field trips for sample collection. We appreciate technical and laboratory input by Jane Borch, Jani Christiansen, Jonna V. Jensen, Tina Frederiksen and Tina Pedersen at the Technical University of Denmark (Lindholm), and we are grateful for the laboratory contributions offered by Esau Martin, MAAIF. This study was funded by Danish International Development Agency (DANIDA) under the Livestock Wildlife Diseases in East Africa Project (LWDEA), grant number: P104.Dan.8.1.316.

\section{Author details}

${ }^{1}$ Ministry of Agriculture, Animal Industry and Fisheries, P.O. Box 513, Entebbe, Uganda. ${ }^{2}$ Makerere University Institute of Environment and Natural Resources, P.O. Box 7298, Kampala, Uganda. ${ }^{3}$ National Veterinary Institute, Technical University of Denmark, Lindholm, DK-4771, Kalvehave, Denmark. ${ }^{4}$ Department of Biology, University of Copenhagen, Ole Maaløes Vej 5, DK2200 Copenhagen N, Denmark. ${ }^{5}$ Department of Veterinary Medicine, Faculty of Veterinary Medicine, Makerere University, Box 7062, Kampala, Uganda. ${ }^{6}$ National Centre for Foreign Animal Diseases, 1015 Arlington Street, Winnipeg MB R3E 3M4, Canada.

\section{Authors' contributions}

CA conceived and designed the study, undertook field work, laboratory studies, data analysis, manuscript preparation, review, corrections and submission. SA, KT, VBM, HRS, ARAO and GJB participated in the supervision of various project activities including field work, laboratory studies, data analysis, manuscript preparation, proof reading and review. FNM participated in field work, laboratory studies, and manuscript proof reading. SNB participated in part of the field work, provision of livestock sequence data and analysis. PN was involved in all the molecular laboratory work. All authors read and approved the final manuscript.

Received: 21 December 2009 Accepted: 11 December 2010 Published: 11 December 2010

\section{References}

1. Alexandersen S, Mowat N: Foot-and-mouth disease: host range and pathogenesis. Curr Top Microbiol Immunol 2005, 288:9-42.

2. Perry BD, Rich KM: Poverty impacts of foot-and-mouth disease and the poverty reduction implications of its control. Vet Rec 2007, 160(7):238-241.

3. Vosloo W, Bastos ADS, Sangare O, Hargreaves SK, Thomas GR: Review of the status of foot and mouth disease in sub-Saharan Africa. Rev Sci Tech 2002, 21:437-449.

4. Thomson GR, Vosloo W, Bastos ADS: Foot and mouth disease in wildlife. Virus Res 2003, 91(1):145-161.

5. Sutmoller P, Thomson G, Hargreaves SK, Foggin CM, Anderson EC: The foot and mouth disease risk posed by African buffalo within wildlife conservancies to the cattle Industry of Zimbabwe. Prev Vet Med 2000, 44:1, 2, 43-60.

6. Bastos ADS, Boshoff Cl, Keet DF, Bengis RG, Thomson GR: Natural transmission of FMD between the African buffalo (Syncerus caffer) and the impala (Aepyceros melampus) in the Kruger National Park, South Africa. Epidemiol Infec 2000, 124:591-598.

7. Anderson EC, Anderson J, Doughty WJ, Drevmo S: The pathogenicity of bovine strains of foot and mouth disease virus for impala and wildebeest. J Wildl Dis 1975, 11(2):248-255.

8. Dawe PS, Flanagan FO, Madekurozwa RL, Sorensen K, Anderson EC, Foggin CM, Ferris NP, Knowles NJ: Natural transmission of foot-andmouth disease virus from African buffalo (Syncerus caffer) to cattle in a wildlife area of Zimbabwe. Vet Rec 1994, 134(10):230-232.

9. Dawe PS, Sorensen K, Ferris NP, Barnett IT, Armstrong RM, Knowles NJ: Experimental transmission of foot-and-mouth disease virus from carrier African buffalo (Syncerus caffer) to cattle in Zimbabwe. Vet Rec 1994, 134(9):211-215.
10. Ryan E, Mackay D, Donaldson A: Foot-and-mouth disease virus concentrations in products of animal origin. Transbound Emerg Dis 2008, 55(2):89-98.

11. Tomasula PM, Konstance RP: The survival of foot-and-mouth disease virus in raw and pasteurized milk and milk products. J Dairy Sci 2004, 87(4):1115-1121.

12. Van Bekkum JG, Frenkel HS, Frederiks HHJ, Frenkel S: Observations on the carrier state of cattle exposed to foot-and-mouth disease virus. Tijdschr. Diergeneeskd 1959, 84:1159-1164.

13. Van Bekkum JG, Frenkel HS, Frederiks HHJ, Frenkel S: Observations on the carrier state of cattle exposed to foot-and-mouth disease virus. Bull Int Epizoot 1959, 51:917-922.

14. Alexandersen S, Zhang Z, Donaldson Al: Aspects of the persistence of foot-and-mouth disease virus in animals-the carrier problem. Microbes Infect 2002, 4(10):1099-1110.

15. Condy JB, Hedger RS, Hamblin C, Barnett IT: The duration of the foot-andmouth disease virus carrier state in African buffalo (i) in the individual animal and (ii) in a free-living herd. Comp Immunol Microbiol Infect Dis 1985, 8(3-4):259-265.

16. Gainaru MD, Thomson GR, Bengis RG, Esterhuysen JJ, Bruce W, Pini A: Footand-mouth disease and the African buffalo (Syncerus caffer). II. Virus excretion and transmission during acute infection. Onderstepoort J Vet Res 1986, 53(2):75-85.

17. Bronsvoort BM, Parida S, Handel I, McFarland S, Fleming L, Hamblin P, Kock R: Serological survey for foot-and-mouth disease virus in wildlife in eastern Africa and estimation of test parameters of a nonstructural protein enzyme-linked immunosorbent assay for buffalo. Clin Vaccine Immunol 2008, 15(6):1003-1011.

18. Hargreaves SK, Foggin CM, Anderson EC, Bastos AD, Thomson GR, Ferris NP, Knowles NJ: An investigation into the source and spread of foot and mouth disease virus from a wildlife conservancy in Zimbabwe. Rev Sci Tech 2004, 23(3):783-790.

19. Vosloo W, Thompson PN, Botha B, Bengis RG, Thomson GR: Longitudinal study to investigate the role of impala (Aepyceros melampus) in footand-mouth disease maintenance in the Kruger National Park, South Africa. Transbound Emerg Dis 2009, 56(1-2):18-30.

20. Ayelet G, Mahapatra M, Gelaye E, Egziabher BG, Rufeal T, Sahle M, Ferris NP, Wadsworth J, Hutchings GH, Knowles NJ: Genetic characterization of footand-mouth disease viruses, Ethiopia, 1981-2007. Emerg Infect Dis 2009, 15(9):1409-1417.

21. Sahle M, Dwarka RM, Venter EH, Vosloo W: Comparison of SAT-1 foot-andmouth disease virus isolates obtained from East Africa between 1971 and 2000 with viruses from the rest of sub-Saharan Africa. Arch Virol 2007, 152(4):797-804

22. Bastos AD, Anderson EC, Bengis RG, Keet DF, Winterbach HK, Thomson GR: Molecular epidemiology of SAT 3-type foot-and-mouth disease. Virus Genes 2003, 27(3):283-290.

23. Kalema-Zikusoka G, Bengis RG, Michel AL, Woodford MH: A preliminary investigation of tuberculosis and other disease in African buffalo (Syncerus caffer) in Queen Elizabeth National Park, Uganda. Onderstepoort $J$ Vet Res 2005, 72(2):145-151.

24. Ayebazibwe C, Mwiine FN, Balinda SN, Tjørnehøj K, Muwanika VB, Ademun ARO, Siegismund HR, Alexandersen S: Antibodies against footand-mouth disease (FMD) virus in African buffalos Syncerus caffer) in selected National Parks in Uganda (2001-2003). Transbound Emerg Dis 2010, 57(4):286-292.

25. WRLFMD: Representative strains for each FMDV topotype. World reference laboratory for foot-and-mouth disease [http://www.wrlfmd.org/ fmd_genotyping/prototypes.htm], Accessed: 20/11/2009.

26. Balinda SN, Belsham GJ, Masembe C, Sangula AK, Siegismund HR, Muwanika VB: Molecular characterization of SAT 2 foot-and-mouth disease virus from post-outbreak slaughtered animals: implications for disease control in Uganda. Epidemiol Infect 2010, 138(8):1204-1210.

27. Bengis RG, Thomson GR, Hedger RS, De Vos V, Pini A: Foot-and-mouth disease and the African buffalo (Syncerus caffer). 1. Carriers as a source of infection for cattle. Onderstepoort J Vet Res 1986, 53(2):69-73.

28. Vosloo W, Bastos AD, Kirkbride E, Esterhuysen JJ, van Rensburg DJ, Bengis RG, Keet DW, Thomson GR: Persistent infection of African buffalo (Syncerus caffer) with SAT-type foot-and-mouth disease viruses: rate of fixation of mutations, antigenic change and interspecies transmission. J Gen Virol 1996, 77(7):1457-1467. 
29. Thomson GR, Vosloo W, Esterhuysen JJ, Bengis RG: Maintenance of foot and mouth disease viruses in buffalo (Syncerus caffer Sparrman, 1779) in southern Africa. Rev Sci Tech 1992, 11(4):1097-1107.

30. Thomson GR: The role of carrier animals in the transmission of foot and mouth disease. Comprehensive Reports on Technical Items Presented to The International Committee or to Regional Commissions 1996, 87-103.

31. Bruckner GK, Vosloo W, Du Plessis BJ, Kloeck PE, Connoway L, Ekron MD Weaver DB, Dickason CJ, Schreuder FJ, Marais T, et al: Foot and mouth disease: the experience of South Africa. Rev Sci Tech 2002, 21(3):751-764.

32. Sutmoller P, Thomson GR, Hargreaves SK, Foggin CM, Anderson EC: The foot-and-mouth disease risk posed by African buffalo within wildlife conservancies to the cattle industry of Zimbabwe. Prev Vet Med 2000, 44(1-2):43-60.

33. Thomson GR: Overview of foot and mouth disease in Southern Africa. Rev Sci Tech 1995, 14(3):503-520.

34. Sangula AK, Belsham GJ, Muwanika VB, Heller R, Balinda SN, Masembe C, Siegismund HR: Evolutionary analysis of foot-and-mouth disease virus serotype SAT 1 isolates from East Africa suggests two independent introductions from southern Africa. BMC Evol Biol 2010, 10:371.

35. Mwiine FN, Ayebazibwe C, Olaho-Mukani W, Alexandersen S, Balinda SN, Masembe C, Ademun AROkurut, Christensen LS, Sørensen KJ, Tjørnehøj K: Serotype-specificity of antibodies against foot and mouth disease virus in cattle in selected districts in Uganda. Transbound Emerg Dis 2010, 57(5):365-74.

36. Hedger RS, Forman AJ, Woodford MH: Foot-and-mouth disease in East African buffalo. Bull Epiz Dis Afr 1973, 21:90-99.

37. UWA: General Reconnaissance flights and ground based estimates. Research Monitoring Report Uganda Wildlife Authority Kampala; 2006.

38. Harthoorn AM: The chemical capture of Animals. A guide to the chemical restraint of wild and captive animals. Bailliere and Tindall London; 1976, 416

39. Kock M, Meltzer D, Burroughs R: Chemical and physical restraint of wild animals. A training and field manual for African species. Zimbabwe Veterinary Association Wildlife Group and International Wildlife Veterinary Services (Africa), South Africa. 2006, 283.

40. Averbeck C: Population Ecology of Impala (Aepyceros melampus) and community-based wildlife conservation in Uganda. Fakultät für Ernährung, Landnutzung und Umwelt, Technische Universität München; 2002 [http://tumb1.biblio.tu-muenchen.de/publ/diss/ww/2002/averbeck.pdf], Accessed: 10/3/08

41. Sorensen KJ, de Stricker K, Dyrting KC, Grazioli S, Haas B: Differentiation of foot-and-mouth disease virus infected animals from vaccinated animals using a blocking ELISA based on baculovirus expressed FMDV $3 A B C$ antigen and a 3ABC monoclonal antibody. Arch Virol 2005, 150(4):805-814.

42. Have $P$, Jensen $M H$ : Detection of antibodies to foot-and-mouth disease virus type $O$ by enzyme-linked immunosorbent assay (ELISA). Proceedings Research Group of the session of the Standing Technical Committee of the European Commission for the Control of Foot-andMouth Disease. Lelystad, Netherlands; 1983, 20-22, Appendix VIII: 44-51.

43. Balinda SN, Tjornehoj K, Muwanika VB, Sangula AK, Mwiine FN, Ayebazibwe C, Masembe C, Siegismund HR, Alexandersen S: Prevalence Estimates of Antibodies Towards Foot-and-Mouth Disease Virus in Small Ruminants in Uganda. Transbound Emerg Dis 2009, 56(9-10):362-371.

44. Bronsvoort BM, Sorensen KJ, Anderson J, Corteyn A, Tanya VN, Kitching RP Morgan KL: Comparison of two $3 A B C$ enzyme-linked immunosorbent assays for diagnosis of multiple-serotype foot-and-mouth disease in a cattle population in an area of endemicity. J Clin Microbiol 2004, 42(5):2108-2114

45. OIE: Foot-and-mouth disease. Manual of standards for diagnostic tests and vaccines for terrestrial animals.[http://www.oie.int/fr/normes/ mmanual/2008/pdf/2.01.05_FMD.pdf], (Accessed 24/11/2010):4-5.

46. Saitou N, Nei M: The neighbor-joining method: A new method for reconstructing phylogenetic trees. Mol Biol Evol 1987, 4:406-425.

47. Felsenstein J: Confidence limits on phylogenies: An approach using the bootstrap. Evol 1985, 39:783-791.

48. Kimura M: A simple method for estimating evolutionary rate of base substitutions through comparative studies of nucleotide sequences. $J$ Molec Evol 1980, 16:111-120.

49. Tamura K, Dudley J, Nei M, Kumar S: Molecular Evolutionary Genetics Analysis (MEGA) software version 4.0. Mol Biol and Evol 2007, 24:1596-1599.
50. Zheng Z, Scott S, Lukas W, Webb M: A greedy algorithm for aligning DNA sequences. J Comput Biol 2000, 7:203-214

51. Hall TA: Bioedit: a user-friendly biological sequence alignment editor and analysis program for windows 95/98/nt. Nucleic Acids Symposium Series 1999, 41:95-98.

doi:10.1186/1746-6148-6-54

Cite this article as: Ayebazibwe et al:: The role of African buffalos (syncerus caffer) in the maintenance of foot-and-mouth disease in Uganda. BMC Veterinary Research 2010 6:54.

\section{Submit your next manuscript to BioMed Central and take full advantage of:}

- Convenient online submission

- Thorough peer review

- No space constraints or color figure charges

- Immediate publication on acceptance

- Inclusion in PubMed, CAS, Scopus and Google Scholar

- Research which is freely available for redistribution

Submit your manuscript at www.biomedcentral.com/submit
Ciomed Central 